\title{
Conflict, Displacement, and Inequality of Opportunity
}

\author{
Tuhin K. Das, Sushil K. Haldar, Ivy Das Gupta, and \\ Sudakhina Mitra
}

\begin{abstract}
Various factors affect the ability of internally displaced persons (IDPs) to achieve socioeconomic stability. Aid and repatriation attempts have a short-term impact, whereas opportunities like access to education and healthcare have a long-term impact. Thus, a measurement of inequality of opportunity is needed in order to formulate an appropriate development policy that can achieve socioeconomic stability. The objective of this study is, therefore, to measure inequality of opportunity affecting a community in India that has been displaced for a period of less than twenty years by ethnic conflict. A field survey revealed that IDPs were more deprived than non-IDPs. Inequality of opportunity has been measured using a D-Index, and determinants of the inequality of opportunity have been identified.
\end{abstract}

Keywords ethnic conflict, internally displaced persons, inequality of opportunity, socioeconomic stability, rehabilitation policy

\section{Introduction}

The relief of hardship and the ultimate attainment of socioeconomic stability for internally displaced persons (IDPs) is a long-term process. It takes years to achieve the ultimate goal, and it may involve more than one generation (viz., intergenerational mobility). In spite of government policy and the provision of government funds for resettlement, IDPs may continue to suffer distress for many years after displacement (Ibáñez and Moya 2006). Therefore, it is important that any study of the deprivation suffered by a displaced community at a particular point in time in this long-term dynamic process (i.e., a cross-sectional study) is carefully designed. Many external factors influence this process over time. The provision of aid, repatriation attempts, the attitude of the host community, government policy regarding access to various benefits (that is, opportunities), and other external factors all have a positive or negative impact on the IDPs' 
ability to achieve socioeconomic stability.

Aid and repatriation attempts have a short-term impact. But the provision of opportunities has a long-term impact, in that opportunities, along with choice, motivation, and talent, contribute to the wellbeing of the displaced population over time. For example, higher education is a precondition for intergenerational mobility, which is defined as children enjoying a higher income level than their parents. If the children of IDPs do not have access to higher education due to socioeconomic deprivation, they will be economically deprived in comparison to the same generation of non-IDPs. Thus, it is important to measure those inequalities of opportunity which are assumed to be the determining factors for long-term socioeconomic stability. From a practical point of view, attaining equality in all aspects of opportunity is almost impossible. In that case, some basic opportunities, such as access to housing, healthcare, education, and employment, should be specified.

The present study deals with such a situation in India. The target group consists of IDPs who have been displaced for a protracted period of less than twenty years. This period is not long enough to verify the hypothesis concerning intergenerational mobility (or socioeconomic stability), especially for displaced people. The present study is, therefore, not aimed at investigating how inequality of opportunity impacts socioeconomic stability. The first objective of this study is to measure inequality of opportunity in a community in India that has been internally displaced by ethnic conflict. The next objective is to identify the economic and demographic factors that influence the community's access to opportunities. The final objective is to investigate whether the existing rehabilitation policy is helping to reduce inequality of opportunity.

\section{Measuring Inequality of Opportunity}

There are two major approaches in inequality studies (Phillips 2004): (1) inequality of outcomes in various dimensions of human wellbeing, for example, inequality of income, standard of living, state of health, and educational attainment (Alkire 2002; Bourguignon and Morrisson 2002), and (2) inequality of opportunity, for example, unequal access to housing, land, credit, technical assistance and training, basic infrastructure, health coverage, education, and employment (Cogneau and Mesplé-Somps 2008; Ibáñez and Velásquez 2009). But these two types of inequality are not independent of each other. Marrero and Rodríguez (2011) find that inequality of opportunity has a direct impact on outcome inequality. Brunori, Ferreira, and Peragine (2013) observe that the human opportunity index (HOI) is closely correlated with the human development index (HDI). In fact, equality of outcomes is the result of various factors in society (Barros et al. 2009), including inequality of conditions due to 
differences in family resources and location; inequality of exogenous genetic factors like differences in talent and motivation; inequality of individuality, such as individual choice and effort; and inequality due to uncertain factors referred to as "post-natal luck" in the literature.

Among these factors, inequality of conditions can be explained as inequality of opportunity. This kind of inequality is associated with differences in predetermined circumstances such as location, gender, race, socioeconomic group, etc. Due to these differences in circumstances, people's opportunities vary and this affects their outcomes. Here, institutions play a role in reducing differences by introducing policies that ensure that everyone has an equal opportunity to reach the same level of outcome. Thus, policy has a role in reducing unequal treatment among individuals who are supposed to be treated equally in the absence of discrimination (Capéau et al. 2012).

In order to formulate appropriate public policies to provide equal opportunities for all, it is essential first of all to measure levels of inequality. Equality of opportunity is a theoretical principle. Some recent studies have been dedicated to empirically establishing this principle using computable measures, although they have encountered many methodological and empirical problems that are often difficult to resolve (Ramos and Van de gaer 2012). However, it is not the purpose of this study to review the empirical literature.

Our purpose here is to use the concept of inequality of opportunity to assess the deprivation of IDPs. If the target group has experienced a protracted period of displacement, then it would be logical to measure the inequality of opportunity rather than the inequality of outcomes, since the former will ultimately influence the latter in the long run. Thus, measuring inequality of opportunity and identifying its determinants will help us explore the linkage between empirical results and existing policy for IDPs. It will enable governments to amend their policies in the future in order to reduce inequality of opportunity. The linkage is established via an econometric model in which variations in inequalities have been observed through the policy parameters for IDPs.

\section{Inequality of Opportunity and Internal Displacement in Northeast India}

According to "Protecting Internally Displaced Persons: A Manual for Law and Policymakers" (Brookings Institution and the University of Bern 2008), national authorities have the primary duty and responsibility to physically protect IDPs, to allow them to pursue their independent livelihoods, and provide access to training, education, and healthcare opportunities. Moreover, governments should only make efforts to repatriate IDPs when it is clear that their safety can be guaranteed. Repatriation programs often fail, even if security is ensured. 
Some of the IDPs may have been poor, marginalized, or landless prior to their displacement and they may not have a home or a means of livelihood to which they can return. In these circumstances, policy formulation is critical because these marginalized and vulnerable IDPs will struggle to resettle after repatriation. Therefore, rehabilitation policies on humanitarian grounds should be aimed at reducing inequality of opportunity among these vulnerable groups by integrating them into local social services and allowing them access to jobs, education, and healthcare opportunities; otherwise another conflict might break out.

India has experienced internal displacement as a result of communal violence and armed conflicts. One of the worst-affected regions is that of the northeast states. The northeast region of India comprises eight states-Assam, Nagaland, Manipur, Arunachal Pradesh, Mizoram, Tripura, and Sikkim (Sikkim was included in the northeast in 2003). This region is connected to the rest of India by a small corridor of land and it has borders with Bhutan, Myanmar, Bangladesh, and China. Ninety-nine percent of the northeast's boundary is international. The region is ethnically, linguistically, and culturally distinct from other parts of India, and this cultural and ethnic diversity is one of the major sources of conflict there. The types of conflict that have afflicted the northeast range from separatist movements to intercommunity, communal, and interethnic conflicts (Heinrich Boll Stiftung, India 2009).

The economic growth rate in the northeast states is low, mainly on account of conflicts and violence. It is widely acknowledged that internal or external conflicts are the major obstacles to development of any kind (Institute for Economics and Peace 2012). Conflicts cripple the economy and the very idea of development economics is suppressed to some extent. Conflict negatively affects physical and social capital, weakens institutional capacity, and generates inefficiency (Kim and Conceicao 2010). One consequence is low levels of investment in both the physical and social sectors, since conflict makes it impossible for investors to secure long-term returns. Ultimately, conflict impedes human development, which in turn decreases productivity, leading to lower economic growth. This low level of growth then intensifies the risk of further conflict. In this way, a region becomes trapped in a "conflict-underdevelopment" cycle.

This inverse relationship between industrial growth and violence has been observed in the northeast states of India (Das et al. 2015). Conflict and violence have led to low levels of investment, both in industry and in the social and physical infrastructure, mainly on account of uncertainty and security concerns. A lack of higher educational institutions and job opportunities is a common phenomenon in regions that are affected by conflict. This is the case in the northeast, where the majority of educated youths remain unemployed due to a lack of industries (Konwar and Chakraborty 2013). Again, conflicts damage and destroy social infrastructure like schools and hospitals. Health services and educational institutions are often deliberately targeted by armed groups. 
Thus, the people of the northeast region suffer from an inability to access basic opportunities like higher education, healthcare, and employment. Against this backdrop, it would be interesting to examine how the opportunities available to IDPs compare with those of the rest of the population in this region.

In order to carry out such an analysis, IDPs in the northeast need to be uniquely identified, and that is difficult for various reasons (Norwegian Refugee Centre, Internal Displacement Monitoring Centre 2014). Firstly, persons, even if they remain displaced, are not counted as IDPs once the official camps are closed. Secondly, there is no information about those IDPs who are assumed to be dispersed in urban areas. Nevertheless, it is possible to obtain a good estimate of the number of IDPs from the Bru people who fled their homes in Mizoram state in 1997 and 2009 due to conflict with the Mizo over demands for a homeland and who sought refuge in the state of Tripura. According to the Indian Ministry of Home Affairs (2014), about five thousand families consisting of approximately thirty thousand Bru (also called Reang or Riang) migrated from western Mizoram from October 1997 onwards. The Bru migrants are sheltered in six relief camps set up in the Kanchanpur subdivision of north Tripura.

The situation deteriorated further after the emergence of Bru rebel groups. The Bru Liberation Front of Mizoram (BLFM) was launched in 2003. This rebel group, together with the Bru National Liberation Front (BNLF), is fighting for an autonomous district council for the Bru inside Mizoram (Bhattacharjee 2014). Although a memorandum of understanding (MoU) was signed between Bru rebel groups and the Mizoram government in April 2005, some BLFM and BNLF militants are continuing their terrorist activities. The Tripura state administration complains that Bru IDPs have occupied about 773 acres of forest land, damaging the biodiversity and ecology of the entire central-eastern part of Kanchanpur subdivision (IANS 2015a). According to the same source, the growing number of clashes between Bru IDPs and the indigenous population of Tripura, as well as insurgency activities involving at least three militant outfits in the camps, is a major law and order problem.

There have been attempts to return the Bru refugees to their homes in Mizoram. The Ministry of Home Affairs has approved financial assistance and logistical support to the Mizoram and Tripura state governments to enable the peaceful repatriation process. Although repatriation started in 2010, only a few families have returned home, because most of the Bru IDPs are worried about their safety and livelihoods (IANS 2015b). According to the Ministry of Home Affairs (2014), only about 1,210 Bru families have been repatriated so far; the majority remain displaced. Here, the question arises, can the unwillingness of the Bru IDPs to return home to Mizoram be explained solely in terms of security, or are there other reasons, such as a lack of opportunities in Mizoram, for their reluctance to return? It may be that, as explained earlier, the Bru IDPs were poor, marginalized, or landless prior to their displacement and they have no 
homes or livelihoods to which they can return. A field survey is necessary if we are to answer that question. The Ashapara relief camp in the Dasda community development block in Kanchanpur subdivision, North Tripura, was selected as the location for this survey.

\section{Methodology}

The survey was carried out in two stages in 2015. In the first stage, a complete list of households was compiled and basic information (year of internal displacement, family structure, etc.) was collected. Also, the draft questionnaire for the detailed household survey was tested and revised at that stage by means of a survey of twenty households selected at random. All of the 650 households in the selected relief camp were displaced in 1997. In the second stage, 380 households were selected from the complete list using a random sampling method, and a detailed household survey was carried out. The sample size was 10 percent of the total number of displaced Bru households in Tripura, which was about 3,800 after the partial repatriation. The survey was based on a comparatively small sample size instead of a sample size determined on the basis of a particular indicator, for example, income, education, or health, because the present study focuses on several indicators rather than just a single indicator (Department of Economic and Social Affairs 2005).

Additionally, 380 households from neighboring villages, members of the same Riang tribe but indigenous to Tripura, were randomly selected to form a population comprised of both groups. The selected villages were Rambahadur Para, Pusingrai Para, 4 No. Colony, and Helen Para in the same Dasda community development block in North Tripura district. We note here that Bru (or Reang/ Riang) make up more than 16 percent of the total scheduled tribal population in Tripura (Ministry of Tribal Affairs 2013).

The next problem that might arise in a case study of this kind concerns the reliability of household data, especially when the government is planning to repatriate IDPs to their homeland and they are unwilling to return. They have been warned that if they do not return to Mizoram, central government aid will be stopped. Under such circumstances their responses to the survey might not be consistent. To eliminate this problem, an internal consistency reliability test has been carried out (Caro and Cortés 2012) (see Appendix B).

One important part of the survey is the question of livelihood. Sometimes, households' responses to questions related to occupation and expenditure-a proxy variable for income (Paulin and Ferraro 1996) - are not reliable, especially for IDPs. Underreporting of occupation and income/expenditure can be expected when the indigenous population is opposed to the IDPs' economic activities (this will be explained in the next section) and the local authorities 
are trying to repatriate them. For this reason, appropriate methods are used to test the reliability of the data. The test-retest method is often used to judge the reliability of expenditure data (Xu et al. 2007). A certain percentage of the initial respondents are generally surveyed by different investigators at another point in time to see how reliable the responses were. Reliability is measured by a correlation coefficient ( $r$ value). In general, reliability is considered to be good if $r$ $\geq 0.70$.

Internal consistency reliability tests for "access to education" and "access to healthcare" are shown in Table 1. Test values show that most survey data are reliable with respect to acceptable value of CC alpha. The reliability of expenditure and occupation data has not been tested here because IDPs' expenditure mainly consists of government aid in cash and kind. They do have other sources of income, but they did not disclose them fully for various reasons which are explained in detail below.

After the primary data were collected, the living conditions of IDPs (target group) and non-IDPs (comparison group) were compared in order to judge the impact of displacement. This dimension of human development was proposed by Alkire and Santos (2010) and incorporated into the UNDP Human Development Report 2010. Then, access to different opportunities was examined using descriptive statistics. Dissimilarity of access rates was evaluated by applying the method developed by Barros et al. (2009). In their study, the dissimilarity of rates of access to some services was measured for groups defined by circumstance characteristics (for example, family per capita income, gender, family structure, and area of residence-urban or rural) against the average access rate for the same opportunities among the population as a whole. In this context, the groups are IDPs and non-IDPs. Finally, the dissimilarity index (or D-Index), which is a weighted average of the absolute differences of group-specific access rates from the overall average access rate, was calculated (Appendix A). A logistic regression model has been estimated to measure the $\mathrm{D}$-Index. This logistic regression model also reveals the causal relationship between rate of access to opportunity and economic and demographic factors. The implications for policy are considered

Table 1. Internal Consistency Reliability Tests for IDP Data

\begin{tabular}{c|c}
\hline \hline Item & CC alpha (Formula B1 in Appendix B) \\
\hline Access to secondary education & 0.841 \\
\hline $\begin{array}{c}\text { Access to healthcare (considering } \\
\text { immunization of children" and "antenatal } \\
\text { check-up for mothers") }\end{array}$ & $\begin{array}{c}\text { Undetermined since variance = 0, i.e., all have } \\
\text { access to these two aspects of healthcare }\end{array}$ \\
\hline Access to medical care (in case of death) & 0.773 \\
\hline
\end{tabular}

Source: Data were collected and complied by the authors through a field study in 2015 
on the basis of this relationship.

\section{Empirical Results}

The sample survey reveals that the proportion of children in IDP households was higher than it was in the households of non-displaced local Bru (Table 2). The percentage of dependents was also higher for IDPs. The dependency ratio was more than 42 percent in IDP families, whereas it was less than 34 percent among the non-displaced community. IDPs lagged behind the local population in terms of literacy. The literacy rates for male and female non-displaced Bru in the sample were approximately 78 percent and 76 percent, respectively. Rates are slightly lower than those in the 2011 Tripura census data (Government of Tripura, Directorate of Economics and Statistics 2014). This phenomenon can be explained by the exclusion from the sample of non-tribal people who are supposed to be better off than tribal communities in all respects.

One dimension of human development that reveals level of deprivation is "living conditions." Generally, the indicators that are used to represent this dimension are access to electricity, safe drinking water, improved sanitation, house with good walls/floor, clean cooking fuel, and possession of assets like bicycles, motorcycles, radios, refrigerators, telephones, or television sets. Table 3 shows the living conditions of IDPs. "Yes" for non-IDPs in the table does not indicate that all households had this item. For example, 40 percent of non-IDPs had an electricity connection. More than 35 percent of non-IDP households possessed either a brick-built or wooden house. The rest of them had houses built of mud or bamboo. However, results displayed in the table show that IDPs were more deprived than non-IDPs. They had no access to electricity and did not own brick-built or wooden houses. Their assets were mainly bicycles, mobile phones, or battery-operated televisions. But very few IDP households possessed these

Table 2. Demographic Profile

\begin{tabular}{l|c|c}
\hline \hline \multicolumn{1}{c|}{ Statistics } & IDPs & Non-IDPs \\
\hline I. Family Structure (\%) & & \\
a) Male & 42.98 & 45.73 \\
b) Female & 44.08 & 45.66 \\
c) Children & 12.94 & 08.61 \\
\hline II. Literacy Rate (\%) & \\
a) Male & 62.24 & 78.14 \\
b) Female & 62.81 & 75.40 \\
\hline III. Percentage of Dependents & 42.05 & 33.61 \\
\hline
\end{tabular}

Source: Data were collected and complied by the authors through a field study in 2015 
Table 3. Living Conditions

\begin{tabular}{c|c|c|c|c|c}
\hline \hline Groups & Electricity & $\begin{array}{c}\text { Clean cooking } \\
\text { fuel (LPG) }\end{array}$ & $\begin{array}{c}\text { Safe drinking } \\
\text { water (treated } \\
\text { water supply) }\end{array}$ & $\begin{array}{c}\text { House with good } \\
\text { walls/floor (brick- } \\
\text { built/wooden) }\end{array}$ & $\begin{array}{c}\text { Assets (bicycle/ } \\
\text { motorcycle/TV/ } \\
\text { refrigerator/mobile } \\
\text { phone) }\end{array}$ \\
\hline IDPs & No & No & Yes & No & Yes (insignificant) \\
\hline $\begin{array}{c}\text { Non- } \\
\text { IDPs }\end{array}$ & Yes & No & Yes & Yes & Yes \\
\hline
\end{tabular}

Source: Data were collected and complied by the authors through a field study in 2015

assets.

The IDPs received regular government aid, but the average annual amount of aid received by IDP households was equivalent to just under 60 percent of the average annual expenditure of non-IDP Riang resident in Tripura (Figure 1). The government aid provided for IDPs was both in cash and kind, and included cash for daily expenditure and annual maintenance, rice, salt, sandals, garments, blankets, and mosquito nets. Aid in kind has been valued at the current market price. The central government has provided this aid to IDPs through the state government since 1997, the year of their displacement. Apart from government aid, IDPs also have some income from earnings. Thus it is expected that their total consumption, including aid, will be not much below that of non-displaced

Figure 1. Household Expenditure and Government Aid

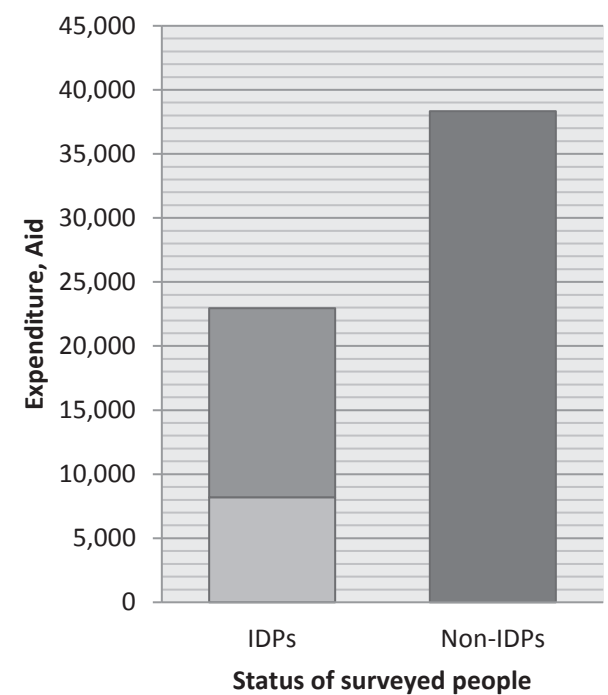

Average government aid per $\mathrm{HH}$ (kind - valued at market price)

$\square$ Average government aid per $\mathrm{HH}$ (cash)

Average annual expenditure incurred by $\mathrm{HH}$

Source: Data were collected and complied by the authors through a field study in 2015 
households. This might be one reason why the majority of IDPs were not willing to return home in spite of the government's repatriation policy and the approved rehabilitation package. This was especially the case for those who were poor, marginalized, or landless prior to their displacement and did not have homes or livelihoods to which they could return. Now we will deal with the opportunities that are essential for achieving the long-term stability of IDPs.

The first opportunity that should be discussed is the IDPs' access to jobs. Survey data show that nearly 55 percent of them were day laborers, 32 percent were cultivators, and 14 percent were involved in business (mainly small traders). The rest were engaged in handicrafts, involving the making and selling of domestic objects such as bamboo baskets. The occupational pattern depicted in Table 4 shows that they had no access to the service sector. In general, there is a lack of employment opportunities in the service sector in northeast India due to the region's slower pace of industrialization and economic growth (Indian Chamber of Commerce 2013). Still, there is some inequality of occupational opportunity between displaced and non-displaced Bru.

Cultivation implies the possession of farmland. Since Bru IDPs have refugee status in Tripura, they are not entitled to possess officially authorized farmland. However, they do illegally occupy state-owned fallow land (khas land, known locally as tilla jami), and they reported this in the survey. IDPs have been trying to use khas land for jhum or shifting cultivation (mostly practiced on thickly forested hillsides). If they do this they face constant opposition from local people, so most of them are employed as day laborers.

Over the last few years, the Kanchanpur economy has been affected by the availability of cheap IDP labor which benefits employers but has an adverse effect on indigenous day laborers. Reduced wage rates for day labor, which is the second-most-important occupation after cultivation among non-IDPs, is contributing to the conflict between the two groups (IANS 2015c). Non-IDPs cultivate legally occupied land (dhani/naal jami, known locally as rayoti jami) as well as illegally occupied land (tilla jami) (Government of Tripura 2007).

Financial inclusion is another opportunity or service that financial

Table 4. Pattern of Occupation

\begin{tabular}{l|c|c}
\hline \hline \multicolumn{1}{c|}{ Occupation (\%) } & IDPs & Non-IDPs \\
\hline Day Labor & 54.47 & 36.68 \\
Cultivation & 31.58 & 44.20 \\
Services & 00.00 & 05.33 \\
Business/small trading & 13.68 & 07.52 \\
Handicraft & 00.26 & 05.96 \\
Others & 00.00 & 00.31 \\
\hline
\end{tabular}

Source: Data were collected and complied by the authors through a field study in 2015 
institutions (for example, banks) deliver to disadvantaged sections of society at an affordable cost. These services include savings, payments, transfers, credit, and insurance. According to the 2011 census, nearly 59 percent of households made use of banking services in India (Bhaskar 2014). Generally, identity documents are required to access such services, and IDPs in Tripura do not have these (Table 5 ). The government of India has recently simplified the procedures for opening a bank account, and an introduction from an existing account holder who satisfies all the requirements will allow an individual with no identity documents to open an account (Jeganathan 2015). In spite of this simplification of procedures, all the displaced households were financially excluded. However, the National Commission for Protection of Child Rights (NCPCR) asked the Tripura government to allow the IDPs to open bank accounts, as the Reserve Bank of India had issued instructions to allow basic savings accounts for all (Karmakar 2013).

A third important opportunity is IDPs' access to education. Repatriation of Bru IDPs is the top priority for both the central and state governments. But leaders of the IDPs always claim that they would willingly return to their homeland in Mizoram if adequate land, compensation, and proper security could be provided (Shillong Times 2014). Failure to make these provisions has slowed down the repatriation process. Little attention has been paid to education and healthcare provision for the IDPs because the ultimate aim is repatriation. Also, it was reported that there are no high schools near the relief camps.

This survey revealed that the minimum distance between high (secondary) schools and the IDP respondents' households was more than two kilometers, whereas it was less than one kilometer for some non-displaced Bru households (Table 6). Levels of education among the Bru IDPs are depicted in Figure 2. Completed school years according to age show that IDPs (both male and female) lag behind permanent residents of Tripura belonging to the same tribe, especially

Table 5. Financial Inclusion and Social Identity

\begin{tabular}{l|l|l}
\hline \hline \multicolumn{1}{c|}{ Social and financial rights } & \multicolumn{1}{c}{ IDPs } & \multicolumn{1}{c}{ Non-IDPs } \\
\hline Bank account & No (in Tripura) & Yes \\
\hline Voter card after displacement & No (in Tripura) & Yes (in Tripura) \\
\hline Voter card before displacement & Yes (in Mizoram) & - \\
\hline Ration card after displacement & No (in Tripura) & Yes (in Tripura) \\
\hline Ration card before displacement & No (in Mizoram) & - \\
\hline Birth certificate after displacement & Yes (issued since year 2000) & Yes (in Tripura) \\
\hline Birth certificate before displacement & Yes (in Mizoram) & - \\
\hline Source: Data we collected and complied & the author throug a fidd stud in 2015
\end{tabular}

Source: Data were collected and complied by the authors through a field study in 2015 
Figure 2. Completed School Years (Average) According to Age

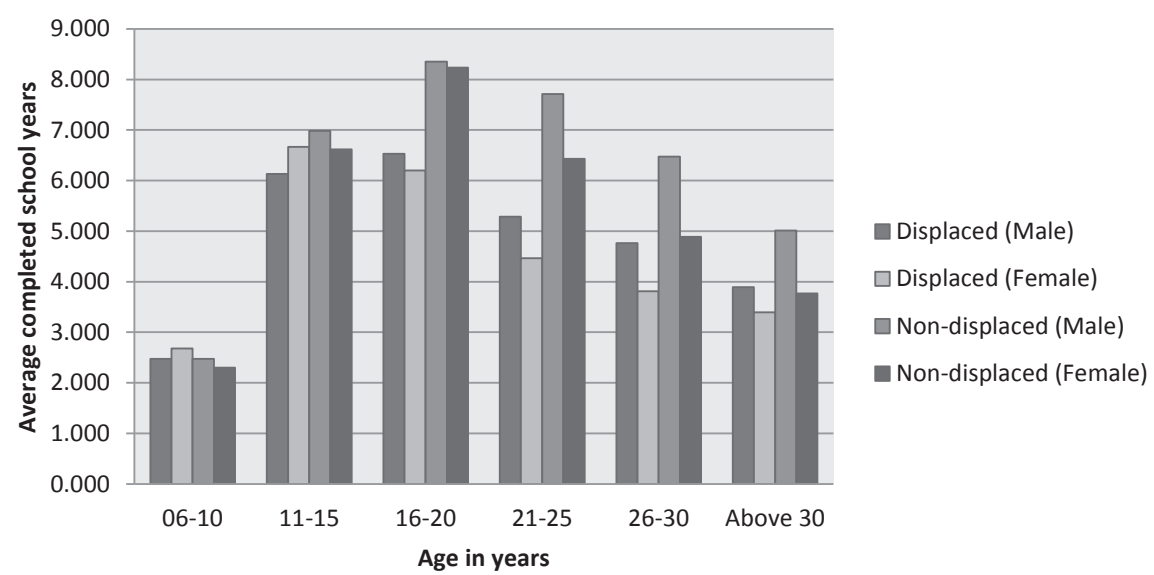

Source: Data were collected and complied by the authors through a field study in 2015

in post-primary education in age group 6-10 years. Interestingly, female IDPs are ahead of male IDPs in school education up to age 15. But the overall scenario for both IDPs and non-IDPs is that females lag behind males in education.

In general, school dropout rates are higher in the northeast states than they are in the rest of India. The main reason for this is the conflict situation in the region. The uncertainty and security concerns caused by conflict account for the low levels of investment in industry and the social and physical infrastructure. A lack of higher education institutions and job opportunities is common in conflictaffected regions. The majority of the educated youths in the northeast remain unemployed due to the lack of industry, which in turn increases school dropout rates. Completed school years in age groups above 20 years decline among both the displaced and non-displaced communities according to survey results.

Access to healthcare is another important opportunity from the point of view of human development. The distance of healthcare facilities from place of residence is more or less the same for both displaced and non-displaced Bru. They have equal access to primary health centers, the subdivision hospital, and local quacks (Table 6). But IDPs have no access to a qualified private practitioner or a private nursing home when they are sick. The reason for this is their poverty. All children in both groups were given a full course of immunizations, and pregnant women were given antenatal check-ups. Medical treatment before death during the last five years was recorded during the field survey. Nearly 27 percent of the deceased persons among the IDPs had been admitted to hospital before death, whereas the proportion was more than 35 percent among non-displaced Bru. Nearly 51 percent of the deceased IDPs and 60 percent of the deceased nonIDPs died at home but had been treated by medical practitioners. The remainder 
Table 6. Access to Physical Infrastructure

\begin{tabular}{l|c|c}
\hline \hline \multicolumn{1}{c|}{ Access to facilities } & IDPs & Non-IDPs \\
\hline Minimum distance of primary school from residence & $1.50 \mathrm{~km}$ & $0.25 \mathrm{~km}$ \\
\hline Minimum distance of secondary school from residence & $2.50 \mathrm{~km}$ & $0.50 \mathrm{~km}$ \\
\hline Minimum distance of subcenter from residence & $1.50 \mathrm{~km}$ & $0.25 \mathrm{~km}$ \\
\hline Minimum distance of primary health center from residence & $2 \mathrm{~km}$ & $0.50 \mathrm{~km}$ \\
\hline Minimum distance of subdivisional hospital from residence & $12 \mathrm{~km}$ & $11 \mathrm{~km}$ \\
\hline $\begin{array}{l}\text { Medical treatment received from where } \\
\text { [qualified private practitioner (QPP), quack (QK), subcenter (SC), } \\
\text { primary health center (PHC), subdivisional hospital (SDH), private } \\
\text { nursing home (PNH)] }\end{array}$ & $\begin{array}{c}\text { QHC, SDH, } \\
\text { QPP, PHC, } \\
\text { SDH, QK, } \\
\text { Immunization of children }\end{array}$ & Yes \\
\hline $\begin{array}{l}\text { Antenatal check-up for mothers } \\
\begin{array}{l}\text { Percentage of deceased persons (during last 5 years) admitted to } \\
\text { hospital before death }\end{array}\end{array}$ & Yes & Yes \\
\hline $\begin{array}{l}\text { Percentage of deceased persons (during last 5 years) died at home } \\
\text { but treated by medical practitioner }\end{array}$ & 50.75 & 60.00 \\
\hline
\end{tabular}

Source: Data were collected and complied by the authors through a field study in 2015

of the deceased persons died at home without medical attendance. Thus access to medical care was better for non-displaced Bru than for IDPs.

Based on the above analysis, the relative frequencies of access to different kinds of opportunities have been plotted in Figure 3 (Wallsten et al. 1997). Relative frequency is measured by the ratio $\mathrm{m}_{\mathrm{A}} / \mathrm{n}_{\mathrm{i}}$, where $\mathrm{m}_{\mathrm{A}}=$ number of respondents with access to opportunity " $\mathrm{A}$ " in group "i" and $\mathrm{n}_{\mathrm{i}}=$ total number of respondents in group " $\mathrm{i}$ " (say, children belonging to either the IDP or nonIDP group). Access to service sector jobs and financial inclusion were totally absent among IDPs. All IDPs and non-IDPs had access to primary education, immunization of children, and antenatal check-ups for pregnant women. There is some degree of inequality between the two groups in terms of (1) access to high school education (above the eighth grade among age group 16-29) (Angloinfo 2000), (2) access to farmland, and (3) access to medical attendance before death.

Of these three indicators, possession of farmland by IDPs is questionable due to the need for official authorization. Both IDPs and non-IDPs were observed to access medical treatment via the public health services (viz., subcenter, primary health center, and subdivision hospital), although there was some disparity in access to medical attendance before death. In spite of this disparity, this indicator shows a weak value for both IDP and non-IDP groups. Further improvement is needed for both groups. Here, we select only one opportunity, access to high 
Figure 3. Relative Frequencies of Access to Different Opportunities

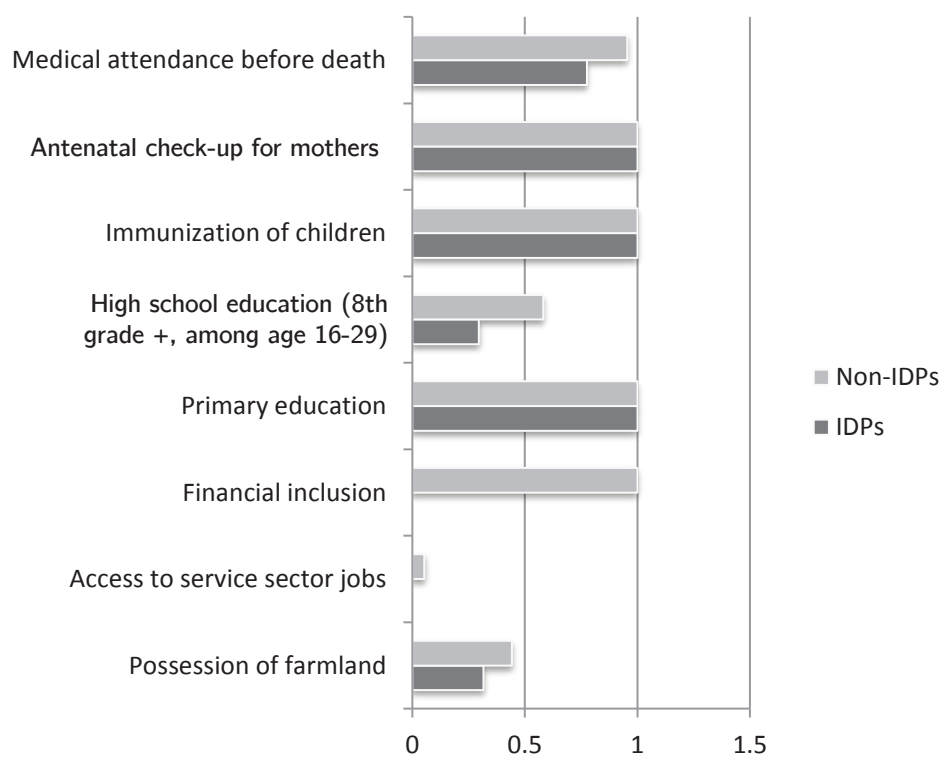

Source: Data were collected and complied by the authors through a field study in 2015

school education, for further analysis.

The dissimilarity index (or D-Index) has been measured with reference to this indicator using equations (A1) and (A2) in Appendix A, based on the empirical results of the following logistic regression model:

(i) $\operatorname{logit}\left(\mathrm{E}\left[Y_{i} \mid x_{1, j}, \ldots, x_{m, j}\right]\right)=\operatorname{logit}\left(p_{j}\right)=\beta_{0}+\beta_{1} x_{1, j}+\ldots+\beta_{m} x_{m, j}+u_{i}$ where

(ii) $\operatorname{logit}\left(p_{j}\right)=\ln \left(\frac{p_{j}}{1-p_{j}}\right)$ which after simplification reduces to

(iii) $p_{j}=1 /\left[1+e^{-\left(\beta_{0}+\beta_{1} x_{1, j}+\ldots .+\beta_{m} x_{m, j}+u_{i}\right)}\right]$

In the above equation, $\beta_{i}$ 's are coefficients associated with the explanatory variables $\mathrm{x}_{\mathrm{i}, \mathrm{j}}$ 's of the model. Here $\mathrm{j}(=1,2,3)$ stands for three groups, i.e., IDPs, non-IDPs, and "All” including both IDPs and non-IDPs. The results of the econometric model for the above three groups are shown in Table 7 . The results show that age is a significant variable in all the models from the point of view of the $\mathrm{z}$-value. However, other variables like gender or family income are significant variables explaining access to high school education in some models. For example, male children have more access to high school education, but this variable is not statistically significant for IDPs. The variable is, however, 
Table 7. Econometric Estimation of Logistic Models

\begin{tabular}{l|c|c|c}
\hline \multirow{2}{*}{ Variables } & \multicolumn{3}{|c}{ Coefficients associated with variables in the model for: } \\
\cline { 2 - 4 } & IDPs & Non-IDPs & All \\
\hline Age & $-0.268(-3.97)$ & $-0.159(-4.18)$ & $-0.156(-5.26)$ \\
\hline Gender (1 if male, 0 if female) & $0.126(0.36)$ & $0.928(3.20)$ & $0.499(2.31)$ \\
\hline Total family members & $1.547(1.98)$ & $0.049(0.16)$ & $-0.478(-3.72)$ \\
\hline $\begin{array}{l}\text { Percentage of dependents in } \\
\text { the family }\end{array}$ & $-0.019(-1.70)$ & $0.001(0.08)$ & $0.005(0.73)$ \\
\hline Occupation as cultivator & $0.436(1.26)$ & $-0.222(-0.77)$ & $0.144(0.67)$ \\
\hline Annual family income/aid & $-0.034 \times 10^{-2}(-2.28)$ & $0.001 \times 10^{-2}(0.48)$ & $0.006 \times 10^{-2}(6.69)$ \\
\hline Constant & $5.483(2.82)$ & $2.733(2.60)$ & $2.588(3.07)$ \\
\hline
\end{tabular}

Note: Figures in parentheses are the $\mathrm{z}$-values

Source: Data were collected and complied by the authors through a field study in 2015

Table 8. The D-index of Inequality of Opportunity

\begin{tabular}{c|c}
\hline \hline Group of people & $\begin{array}{c}\text { The D-index of inequality of opportunity regarding access to high school } \\
\text { education }\end{array}$ \\
\hline IDPs & 0.4999 \\
\hline Non-IDPs & 0.3788 \\
\hline
\end{tabular}

Source: Data were collected and complied by the authors through a field study in 2015

significant when we consider them altogether (fourth column in the table for "All").

The model also shows that access to high school education for children of IDPs increases when IDPs have an income in addition to government aid. This is reflected through the positive coefficient of the "cultivator" variable among the occupations. Another important variable in this model is "annual family income/aid." For the group "All," its impact is positive and statistically significant. For IDPs, however, its impact is negative (as shown by the model). The reason for this is the multicollinearity problem. "Total annual family aid" received by a household is almost proportional to "total family members" of that household, so these two variables are positively correlated.

The D-index of inequality of opportunity is computed using the coefficients in Table 7. It shows that the opportunity to access high school education is not much higher for non-IDPs than it is for IDPs (Table 8). This indicates that the region as a whole is suffering from a lack of secondary education (something that will be discussed in more detail in the next section). Displacement only makes the situation worse. The econometric results discussed above show which factors 
are responsible for this disparity. Other than gender and age, they are mainly job opportunities, income, and dependency ratio in the family. To overcome deprivation amongst this group of people, job opportunities should be created for both male and female adult IDPs. This policy would not only mitigate gender discrimination but also reduce the number of dependents in the family. Job opportunities would also enhance family incomes, ultimately boosting the rate of access to higher education.

\section{Policy Concerns}

Finally, it may be concluded from the above descriptive and quantitative analysis that there is inequality of opportunity between IDPs and non-IDPs (the first objective of this study). The factors that are responsible for this inequality are not only economic (viz., income and occupation) but also demographic, including gender, age, and dependency ratio (the second objective of this study). At this point, we are concerned with evaluating social welfare policy in the light of this empirical analysis of equality of opportunity (the third objective of the study). Policy institutions, especially in the health and education sectors, already make use of the concept and measurement of equality of opportunity in the design and assessment of policies (Kanbur and Wagstaff 2014). Education policy in the northeast states has also been reviewed in the light of this concept. The above analysis shows that existing government policy (that is, government aid to IDPs and compulsory primary education) has helped in reducing inequality to some extent.

Policies that promote higher educational attainment can reduce income inequality in the long run (OECD 2014). Investment, therefore, must start with primary education (which has already been accomplished, see Figure 3), and be continued through high school education so that the target generation can have access to higher education in the future. This will ensure equality of opportunity for children from communities which are socially and financially underdeveloped. It has been observed in the present field study (Figure 2) and the econometric results (Table 7) that among both the displaced and non-displaced communities, members of the younger generation are staying in school longer than their parents did. That is a precondition for intergenerational mobility. Intergenerational mobility is said to be high if people have higher incomes than their parents.

In an effort to tackle the lack of job opportunities in the northeast states, the government of India has introduced a number of higher education initiatives, including setting up such institutions as the All India Institute of Medical Sciences (AIIMS) in Assam, the Indian Institute of Science Education and Research (IISER) in Nagaland, and the Centre for Film Production, Animation 
and Gaming in Arunachal Pradesh (Government of India 2015). These moves are in accordance with the government's "Act East" policy. The aim of the "Act East" policy is to set up manufacturing hubs in Southeast Asia to boost trade and commerce between that region and the landlocked states of northeast India. It is expected that northeast India will benefit from that policy in terms of infrastructure development and employment opportunities-the latter both at home and overseas (Singh 2015).

Regarding public health policy, the Indian government's objective is to achieve "health for all." During his budget speech in 2015, the finance minister quoted from the Upanishads thus, "Sarve bhavantu sukhinah, sarve santu niraamayaah," meaning "may everybody be happy, may everybody be free from illness" (Mazumdar-Shaw 2015). A national "mission mode" program has also been proposed to halt the worsening problem of malnutrition in India (Government of India, Union Budget 2014-2015). Data from the present survey reveal that the level of immunizations of children and antenatal check-ups for expectant mothers among IDP and non-IDP groups has reached 100 percent. However, medical care is still lacking in India. Medical treatment costs money, and is sometimes unaffordable, so people often fail to seek treatment or opt for quack remedies or complementary medicine (Das and Choudhury 2007; Das 2008). The survey results demonstrate that the healthcare situation among IDPs is worse than it is among non-IDPs. One of the major reasons for this is obviously their level of economic deprivation. They need job opportunities so that they can earn money to meet the costs of both medical treatment and higher education.

Policy makers are now faced with two challenging tasks: devising shortterm policies to ease the lives of conflict-affected people while at the same time concluding peace agreements with insurgent groups, and formulating long-term policies for the economic development of the region. Reaching peace agreements is a continuing process as there are many rebel groups in the region. One recent achievement of this sort is the agreement reached with the National Socialist Council of Nagaland (NSCN-IM) which promises to put an end to India's longestrunning insurgency (Hindustan Times 2015). Despite these peace agreements, large numbers of people in the northeast states, including the younger generation, have suffered greatly due to conflicts and subsequent displacement. The government should formulate policies to take care of this.

As mentioned earlier, the displaced Bru in Tripura lag behind the nondisplaced people there in many respects. They need to be provided with equal opportunities, especially higher education, even if they are repatriated. Otherwise, their lack of higher education and related job opportunities will cause another conflict. People throughout the world are now demanding equal opportunities and an end to discrimination. Moreover, it should be kept in mind that income inequality needs to be reduced if equality of opportunity is to be meaningful. If this is achieved, everyone will share the same starting point in life (UNDP 2013). 
Here, it should be kept in mind that there are occupations that should be encouraged in order to bring about equality of opportunity. A low-intensity conflict has been going on between IDPs and non-IDPs regarding jhum (shifting) cultivation in Kanchanpur. This form of cultivation is widely practiced by tribal populations in the northeast states, and the region has nearly 86 percent of the total area devoted to shifting cultivation in India (Patel et al. 2013). This practice is a cause of ecological degradation in hilly areas, so for that reason as well as for reasons of low productivity, jhum cultivation should not be encouraged. People must be provided with alternative sources of income, which is not an easy task (Das and Das 2014). This is something that requires a holistic and integrated approach.

\section{Acknowledgements}

This study has received funding from the Planning and Development Unit, Jadavpur University, India, and the European Union Seventh Framework Programme ([FP7/2007-2013] [FP7/2007-2011]) under Grant Agreement Number 607960 . The authors would like to thank the anonymous reviewers for their helpful comments on the manuscript.

\section{Appendix A}

The D-index of inequality of opportunity is mathematically expressed as:

(A1) $\overline{\mathrm{D}}=\frac{1}{2 \overline{\mathrm{p}}} \Sigma \mathrm{w}_{\mathrm{j}}\left|\hat{\mathrm{p}}_{\mathrm{j}}-\overline{\mathrm{p}}\right|$, and

(A2) $\bar{p}=\Sigma_{1}^{n} w_{j} \hat{p}_{j} ;$

$\mathrm{j}=1 \ldots \mathrm{n} ; \mathrm{w}_{\mathrm{j}}$ is sampling weights and may be assumed to be $\frac{1}{\mathrm{n}}$ for equal weights. In the above expression $\hat{\mathrm{p}}_{\mathrm{j}}$ is the group-specific access rate and $\overline{\mathrm{p}}$ is the overall average access rate. Using a logistic regression model, $\mathrm{p}_{\mathrm{j}} \mathrm{can}$ be estimated as the probability of having access to a particular opportunity, conditional on a person's circumstances (Kovacevic 2010).

\section{Appendix B}

An internal consistency reliability test has been applied to a number of items that are assumed to measure different aspects of the same concept. For example, 
"do your children (aged 12-18 years) have access to secondary education?" and "completed school years of your children (12-18 years)" both reflect the household's access to secondary education. Access to public healthcare is reflected through "do you have access to healthcare?" "immunization of children," "antenatal check-ups for expectant mothers," and "visiting a public health center for medical care." Cronbach's coefficient alpha (CC alpha) measures internal consistency reliability and shows how well the different items complement each other in their measurement of different aspects of the same variable (Cronbach 1951). CC alpha is defined as:

$$
\text { (B1) } \mathrm{CC} \alpha=\left(1-\frac{\sum_{1}^{\mathrm{K}} \mathrm{P}_{\mathrm{i}} \mathrm{Q}_{\mathrm{i}}}{\sigma_{\mathrm{X}}^{2}}\right) \frac{\mathrm{K}}{\mathrm{K}-1}
$$

$\mathrm{K}$ is the number of different aspects of the same concept. $\sigma_{\mathrm{X}}^{2}$ is the variance of the observed total test scores. $P_{i}$ is the proportion scoring 1 on aspect $\mathrm{i}$, and $\mathrm{Q}_{\mathrm{i}}$ $=1-\mathrm{P}_{\mathrm{i}}$. Data are acceptable if $\alpha \geq 0.6$. Data are poor if $0.5 \leq \alpha<0.6$, and are unacceptable if $\alpha<0.5$.

\section{References}

Alkire, Sabina. 2002. “Dimensions of Human Development.” World Development 30 (2): 181-205.

Alkire, Sabina, and Maria Emma Santos. 2010. "Multidimensional Poverty Index." Oxford Poverty \& Human Development Initiative, July. http://www.ophi.org.uk/wp-content/ uploads/OPHI-MPI-Brief.pdf (accessed April 15, 2016).

Angloinfo. 2000. "The School System in India." http://india.angloinfo.com/family/ schooling-education/school-system (accessed August 20, 2016).

Barros, Ricardo Paes de, Francisco H. G. Ferreira, José R. Molinas Vega, and Jaime Saavedra Chanduvi. 2009. Measuring Inequality of Opportunities in Latin America and the Caribbean. Washington DC: World Bank. http://siteresources.worldbank.org/ LACEXT/Resources/258553-1222276310889/Book_HOI.pdf (accessed October 17, 2016).

Bhaskar, P. Vijaya. 2014. "Financial Inclusion in India: An Assessment." Reserve Bank of India Bulletin, January. http://rbidocs.rbi.org.in/rdocs/Bulletin/PDFs/04FS090114SF. pdf (accessed April 23, 2016).

Bourguignon, François, and Christian Morrison. 2002. "Inequality among World Citizens: 1820-1992.” The American Economic Review 92 (4): 727-744.

Brookings Institution, and the University of Bern, eds. 2008. "Protecting Internally Displaced Persons: A Manual for Law and Policymakers." October. www.refworld. org/pdfid/4900944a2.pdf (accessed April 29, 2016).

Brunori, Paolo, Francisco H. G. Ferreira, and Vito Peragine. 2013. "Inequality of Opportunity, Income Inequality and Economic Mobility: Some International Comparisons." IZA Discussion Paper No. 7155. http://ftp.iza.org/dp7155.pdf (accessed 
April 29, 2016).

Capéau, Bart, Lieve Eeman, Steven Groenez, and Miet Lamberts. 2012. "Two Concepts of Discrimination: Inequality of Opportunity versus Unequal Treatment of Equals." ECARES Working Paper 2012-021. https://ideas.repec.org/p/eca/wpaper/2013123943.html (accessed April 27, 2016).

Caro, Daniel H., and Diego Cortés. 2012. "Measuring Family Socioeconomic Status: An Illustration Using Data from PIRLS 2006.” In IERI Monograph Series: Issues and Methodologies in Large-Scale Assessments Volume 5, edited by Matthias von Davier and Dirk Hastedt. http://www.ierinstitute.org/fileadmin/Documents/IERI_ Monograph/IERI_Monograph_Volume_05_Chapter_1.pdf (accessed October 17, 2016).

Cogneau, Denis, and Sandrine Mesplé-Somps. 2008. "Inequality of Opportunity for Income in Five Countries of Africa." Research on Economic Inequality 16: 99-128.

Cronbach, Lee J. 1951. "Coefficient Alpha and the Internal Structure of Tests." Psychometrika 16 (3): 297-334.

Das, Suman, and Madhushree Das. 2014. "Shifting Cultivation in Tripura: A Critical Analysis." Journal of Agriculture and Life Sciences 1 (1): 48-54.

Das, Tuhin K. 2008. "Quack: Their Role in Health Sector." http://dx.doi.org/10.2139/ ssrn.1292712 (accessed September 15, 2016).

Das, Tuhin K., and Dipanwita S. D. Choudhury. 2007. "Are 'Complementary and Alternative Medicines' Alternative to Conventional Medical System? An Economic Evaluation." Applied Economics Letters 14 (9): 697-700.

Das, Tuhin K., Ivy Das Gupta, Sushil K. Haldar, and Sudakhina Mitra. 2015. "Conflicts and Socioeconomic Consequences in Northeast India." Asian Journal of Humanities and Social Studies 3 (1): 79-84.

Department of Economic and Social Affairs. 2005. Designing Household Survey Samples: Practical Guidelines, Studies in Methods. Studies in Methods, Series F, No. 98. New York: Statistics Division, United Nations. http://unstats.un.org/unsd/demographic/ sources/surveys/Series_F98en.pdf (accessed February 2, 2016).

Government of India. 2015. General Budget 2015-16. http://pib.nic.in/budget2015/ budgetdoc/gbEngRelease.pdf (accessed April 20, 2016).

Government of India, Union Budget. 2014-2015. http://india.gov.in/spotlight/unionbudget-2014-2015 (accessed April 4, 2016).

Government of Tripura. 2007. Tripura Human Development Report 2007. http:// planningcommission.nic.in/plans/stateplan/sdr_pdf/tripura\%20hdr.pdf (accessed May 26, 2016).

Government of Tripura, Directorate of Economics and Statistics. 2014 "Tripura at a Glance, 2013-14.” http://ecostat.tripura.gov.in/Tripura\%20At-A-Glance_2013-14.pdf (accessed April 29, 2016).

Heinrich Boll Stiftung, India. 2009. "Conflict in Northeast India: Issues, Causes and Concern." February 28. http://in.boell.org/2009/02/28/conflict-northeast-indiaissues-causes-and-concern (accessed March 29, 2016).

Hindustan Times. 2015. "Centre, Naga Rebels Ink Peace Deal to End Longest Insurgency." August 4. http://www.hindustantimes.com/india-news/indian-govt-signs-landmarkpeace-treaty-with-naga-rebels/article1-1376029.aspx (accessed November 3, 2016).

Ibáñez, Ana Maria, and Andres Moya. 2006. “The Impact of Intra-State Conflict on 
Economic Welfare and Consumption Smoothing: Empirical Evidence for the Displaced Population in Colombia." HiCN Working Paper 23. http://ssrn.com/ abstract $=1392415$ (accessed April 4, 2016).

Ibáñez, Ana Maria, and Andrea Velásquez. 2009. "Identifying Victims from Civil Conflicts: An Evaluation of Forced Displaced Households in Colombia." Journal of Peace Research 46 (3): 431-451.

Indian Chamber of Commerce. 2013. India's North-East: Diversifying Growth Opportunities. https://www.pwc.in/en_IN/in/assets/pdfs/publications/2013/northeast_summit-2013.pdf (accessed April 4, 2016).

IANS (Indo-Asian News Service). 2015a. "Rajnath Singh Visits Myanmar Border, Reviews Manipur Situation." Morung Express, February 13. http://morungexpress.com/rajnathsingh-visits-myanmar-border-reviews-manipur-situation (accessed March 23, 2016).

IANS (Indo-Asian News Service). 2015b. "Mizoram: Bru Leaders Told to Get Ready for Final Six-Month Repatriation Process." Indian Express, March 3. http://indianexpress. com/article/india/india-others/mizoram-bru-leaders-told-to-get-ready-for-final-sixmonth-repatriation-process (accessed April 4, 2016).

IANS (Indo-Asian News Service). 2015c. "Mizoram to Take Back Its Tribal Citizens from Tripura after 18 Years." Business Standard, May 17. http://www.business-standard. com/article/news-ians/mizoram-to-take-back-its-tribal-citizens-from-tripura-after18-years-115051700374_1.html (accessed June 14, 2016).

Institute for Economics and Peace. 2012. A Holistic Approach to Measuring Peace and Conflict. www.worldwewant2015.org/file/290367/download/314773 (accessed April 24, 2016).

Jeganathan, Rajesh. 2015. "Measures for Achieving Financial Inclusion in India." Thought Paper, Infosys India. https://www.edgeverve.com/finacle/resources/thought-papers/ Documents/measures-for-achieving.pdf (accessed April 23, 2016).

Kanbur, Ravi, and Adam Wagstaff. 2014. "How Useful Is Inequality of Opportunity as a Policy Construct?” Policy Research Working Paper WPS6980, World Bank. http:// documents.worldbank.org/curated/en/130991468147875069/How-useful-isinequality-of-opportunity-as-a-policy-construct (accessed April 4, 2016).

Karmakar, Sumir. 2013. "Identity for Bru Refugee Children: Tripura Asked to Do Needful." Telegraph, November 1. http://www.telegraphindia.com/1131101/jsp/northeast/ story_17519164.jsp\#.VT3wUvmSyJ4 (accessed June 18, 2016).

Kim, Namsuk, and Pedro Conceicao. 2010. "The Economic Crisis, Violent Conflict, and Human Development.” International Journal of Peace Studies 15 (1): 29-43.

Konwar, Nitu, and Subhadeep Chakraborty. 2013. "Higher Education Scenario of the North-Eastern India." Indian Journal of Research 2 (3): 78-80.

Kovacevic, Milorad. 2010. "Measurement of Inequality in Human Development: A Review." Human Development Research Paper 2010/35, UNDP. http://hdr.undp.org/ sites/default/files/hdrp_2010_35.pdf (accessed April 4, 2016).

Marrero, Gustavo A., and Juan G. Rodríguez. 2011. "Inequality of Opportunity and Growth.” Documento de Trabajo/Working Paper DT-E-2011-05, Serie Economía. http://www.uv.es/ estevev/DT-E-2011-05.pdf (accessed April 10, 2016).

Mazumdar-Shaw, Kiran. 2015. "Budget 2015: India Needs a Booster Dose for Health for All.” Economic Times, March 6. http://blogs.economictimes.indiatimes.com/ Plainspeak/budget-2015-india-needs-a-booster-dose-for-health-for-all (accessed 
April 29, 2016).

Ministry of Home Affairs. 2014. "Reang Community of Mizoram Taking Refuge in Tripura." Rajya Sabha Starred Question No. 44. http://mha1.nic.in/par2013/par2014pdfs/rs-261114/44.pdf (accessed April 14, 2016).

Ministry of Tribal Affairs. 2013. Statistical Profile of Scheduled Tribes in India. Statistics Division, Government of India. http://ribal.nic.in/WriteReadData/CMS/Documents /201410170519295222004StatisticalProfileofSTs2013.pdf (accessed April 17, 2016).

Norwegian Refugee Centre, Internal Displacement Monitoring Centre. 2014. Global Overview 2014: People Internally Displaced by Conflict and Violence. May. http://www. acnur.org/t3/fileadmin/Documentos/Publicaciones/2014/9958.pdf?view=1 (accessed April 13, 2016).

OECD (Organization of Economic Co-operation and Development). 2014. United States: Tackling High Inequalities, Creating Opportunities for All. June. http://www.oecd.org/ unitedstates/Tackling-high-inequalities.pdf (accessed October 13, 2016).

Patel, Thaneswer, S. Karmakar, J. Sanjog, Sougata Kumar, and Anirban Chowdhury. 2013. "Socio-Economic and Environmental Changes with Transition from Shifting to Settled Cultivation in North-Eastern India: An Ergonomics Perspective." International Journal of Agricultural Science and Research 3 (2): 117-136.

Paulin, Geoffrey D., and David L. Ferraro. 1996. "Do Expenditures Explain Income? A Study of Variables for Income Imputation." Journal of Economic and Social Measurement 22 (2): 106-115.

Phillips, Anne. 2004. "Defending Equality of Outcome." London: LSE Research Online. http://eprints.lse.ac.uk/archive/00000533 (accessed March 29, 2016).

Ramos, Xavier, and Dirk Van de gaer. 2012. "Empirical Approaches to Inequality of Opportunity: Principle, Measures and Evidence.” IZA DP No. 6672. http://ftp.iza.org/ dp6672.pdf (accessed April 26, 2016).

Shillong Times. 2014. "Want Status Like Kashmiri Pandits or Tamil Refugees for Bru Tribals"' August 27. http://www.theshillongtimes.com/2014/08/27/want-status-likekashmiri-pandits-or-tamil-refugees-for-bru-tribals (accessed April 27, 2016).

Singh, Bikash. 2015. "Budget 2015: 'Act East' Policy Initiative, National Institutes a Boon to Northeast." Economic Times, February 28. http://articles.economictimes.indiatimes. com/2015-02-28/news/59612937_1_northeast-india-act-east-investment-promotionpolicy (accessed February 20, 2016).

UNDP (United Nations Development Programme). 2010. Human Development Report 2010. New York: United Nations Development Programme. http://hdr.undp.org/sites/ default/files/reports/270/hdr_2010_en_complete_reprint.pdf (accessed January 28, 2016).

UNDP (United Nations Development Programme). 2013. Humanity Divided: Confronting Inequality in Developing Countries. New York: United Nations Development Programme, Bureau for Development Policy. http://www.undp.org/content/dam/ undp/library/Poverty\%20Reduction/Inclusive\%20development/Humanity\%20 Divided/HumanityDivided_Full-Report.pdf (accessed April 4, 2016).

Wallsten, Thomas S., David V. Budescu, Ido Erev, and Adele Diederich. 1997. "Evaluating and Combining Subjective Probability Estimates." Journal of Behavioral Decision Making 10: 243-268.

Xu, Ke, Frode Ravndal, David B. Evans, and Guy Carrin. 2007. "Household Expenditure 
Data: Results of the World Health Survey." Discussion Paper Number 5, World Health Organization, Geneva. http://www.who.int/health_financing/documents/dp_e_07_5hh_exp_data_reliability.pdf (accessed May 29, 2016).

Tuhin K. Das is Chair Professor of the Planning and Development Unit (a unit of the National Institution for Transforming India Aayog), and former Professor of Economics, Jadavpur University, India. His major publications include "River Bank Erosion Induced Human Displacement and Its Consequences" (Living Review of Landscape Research 2014) and Development Policy Issues in India: Theoretical \& Empirical Studies on Poverty, which he edited (ACB Publications, 2012). Email: tuhin22@hotmail.com

Sushil K. Haldar is Professor of the Department of Economics, Jadavpur University, India. His major publications include "Progress and Constraints of Reproductive Health in India at Sub-National Level: An Exploratory Study" (Health and Population: Perspectives and Issues 2015) and "Economic Growth in South Asia: Binding Constraints for the Future" (Journal of South Asian Development 2015). Email: sushil.haldar@gmail.com

Ivy Das Gupta is an Assistant Professor in the Department of Economics, Bhowanipur Education Society College, India. Her major publications include "Natural Disaster Mitigation in West Bengal" in The Economic Impacts of Natural Disasters, eds. Debarati Guha-Sapir and Indhira Santos (Oxford University Press, 2013) and Growth Structure and Problems in Trade among SAARC Countries (Kalinga Publication, 2000). Email: ivygupta@gmail.com

Sudakhina Mitra is an Assistant Professor in the State Institute of Public Administration and Rural Development, India. Her major publications include "An Assessment of Health Care Infrastructure and Health Care Need in India" (Voice of Intellectual Man - An International Journal 2013) and "Empowerment of Women Workers through MGNREGS: A Case Study from Tripura" (Voice of Intellectual Man - An International Journal 2014). Email: sudakhina.24@gmail.com 
